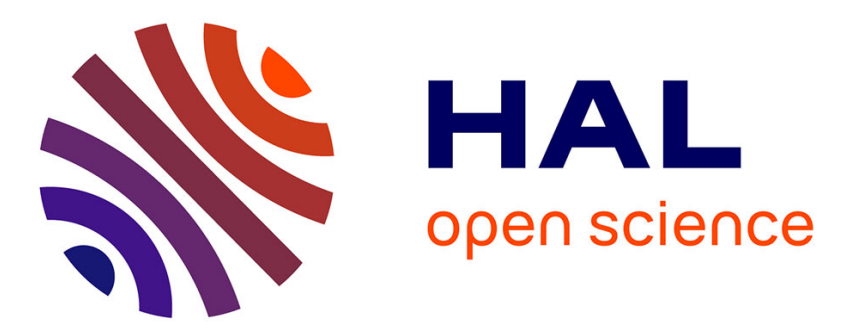

\title{
Anatomical distribution of heavy metals in the scallop Pecten maximus
}

\author{
Yolanda Saavedra, Juan Blanco, Aurora González
}

\section{To cite this version:}

Yolanda Saavedra, Juan Blanco, Aurora González. Anatomical distribution of heavy metals in the scallop Pecten maximus. Food Additives and Contaminants, 2008, 25 (11), pp.1339-1344. 10.1080/02652030802163398 . hal-00577401

\section{HAL Id: hal-00577401 \\ https://hal.science/hal-00577401}

Submitted on 17 Mar 2011

HAL is a multi-disciplinary open access archive for the deposit and dissemination of scientific research documents, whether they are published or not. The documents may come from teaching and research institutions in France or abroad, or from public or private research centers.
L'archive ouverte pluridisciplinaire HAL, est destinée au dépôt et à la diffusion de documents scientifiques de niveau recherche, publiés ou non, émanant des établissements d'enseignement et de recherche français ou étrangers, des laboratoires publics ou privés. 


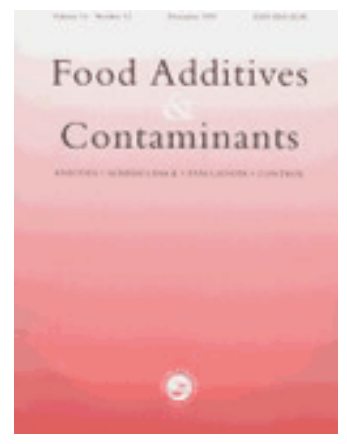

\section{Anatomical distribution of heavy metals in the scallop Pecten maximus}

\begin{tabular}{|r|l|}
\hline Journal: & Food Additives and Contaminants \\
\hline Manuscript ID: & TFAC-2008-033.R1 \\
\hline Manuscript Type: & Original Research Paper \\
\hline Author: & 18-Apr-2008 \\
\hline Complete List of Authors: & $\begin{array}{l}\text { Saavedra, Yolanda; INTECMAR, Chemical contamination } \\
\text { Blanco, Juan; Centro de Investigacións Mariñas, Oceanography } \\
\text { González, Aurora; Universidad de Santiago de Compostela, } \\
\text { Analytical Chemistry }\end{array}$ \\
\hline Methods/Techniques: & Metals analysis - AAS \\
\hline Additives/Contaminants: & Heavy metals \\
\hline Food Types: & Seafood \\
\hline
\end{tabular}

\section{SCHOLARONE Manuscripts}




\title{
Anatomical distribution of heavy metals in the scallop Pecten maximus
}

\author{
Yolanda Saavedra*(1), Aurora González (2) and Juan Blanco (3)
}

(1) Instituto Tecnológico para el Control del Medio Marino de Galicia (INTECMAR) Vilagarcía de Arousa . Spain.

(2) Universidad de Santiago de Compostela. Santiago de Compostela. Spain

(3) Centro de Investigacións Mariñas. Vilanova de Arousa. Spain.

This paper studies the anatomical distribution of $\mathrm{Hg}, \mathrm{Cd}, \mathrm{Pb}, \mathrm{Cr}, \mathrm{Ni}, \mathrm{As}, \mathrm{Ag}, \mathrm{Cu}$ and $\mathrm{Zn}$ in the scallop Pecten maximus and the possible implications in terms of shellfish management. Six organs were analysed: the mantle, gills, foot, digestive gland, kidney and gonad. On the basis of their anatomical distribution, two groups of metals were able to be distinguished: the first included $\mathrm{Pb}, \mathrm{Hg}, \mathrm{Ni}, \mathrm{Zn}$ and $\mathrm{Ag}$; and the second comprised the four other metals studied. The metals in the first group preferentially accumulated in the kidney (except for $\mathrm{Pb}$ ), with generally much lower concentrations in the other organs. The metals in the second group accumulated mainly in the digestive gland. As and $\mathrm{Cu}$ were included in the second group, but they also had particular inter-organ distribution characteristics. Among the edible organs of the scallop, only the adductor muscle contained important proportions of one metal, arsenic (which is very likely accumulated as a non-toxic derivative). A selective evisceration of the metal rich non-edible organs may therefore be considered a reliable measure to be taken with a view to reduce the metal content of scallops used for human consumption. This could be especially relevant for $\mathrm{Cd}$ which is accumulated in high concentrations in the digestive gland.

Keywords: Heavy metals, Anatomical distribution, Scallops

\footnotetext{
* Corresponding autor. Present address: INTECMAR. Peirao de Vilaxoán s/n, Vilagarcía de Arousa E-36611, Pontevedra, Sp. Tel.: +34-986512320; fax: +34-986-512300. E-mail address: ysaavedra@intecmar.org (Y. Saavedra)
} 


\section{Introduction}

The king scallop Pecten maximus is an important resource in Galicia as well as in other areas of EU and Canada and therefore requires close monitoring of its content of substances that could have a harmful effect on human health, such as heavy metals. Other pectinids are known to accumulate large amounts of cadmium, even from unpolluted areas (Stewart and Arnold, 1994; Uthe and Chou, 1987; Francesconi et al., 1993). If the ability of the king scallop to accumulate heavy metals is high, then the exploitation strategy of this species should take into account both the accumulated and the environmental metal concentrations. Moreover, if the metal accumulation capability of this species is very high, as suggested by previous studies, then in some cases, its use as a resource for human consumption would be linked to the ability to eliminate or reduce such contaminants by means of specific treatments. As the different parts of the soft tissues of this species vary in economic value, one of the possible treatments would be the elimination of the most toxic parts, provided that they are the ones with the lowest economic value. This approach has recently been used by the EU to minimise the effects of the accumulation of domoic acid, the main biotoxin responsible for Amnesic Shellfish Poisoning (Fernández et al, 2003).

Previous studies have dealt with metal distribution in various groups of scallop organs, but they did not separate all the possible fractions, taking into account only a reduced sub-set of the dangerous metals (Topping, 1973; Segar et al., 1971). Only a few studies on metal distribution in scallop soft tissues have separated the kidney to analyse metals (Khristoforova et al., 1989; Segar, 1971) even though this organ may be considered an important accumulator. 


\section{Material and Methods}

\section{Sample collection and treatment}

One sample of 36 scallops Pecten maximus was collected in June of 2000 from the Ría de Arousa (NW of the Iberian Penindula) (Figure 1) to study metals in different organs. The scallops in the sample were pooled into 3 batches of 12 individuals each. The soft tissues extracted from scallops of each batch were carefully dissected to obtain the mantle, gills, foot, digestive gland, kidney and gonad (Figure 2). The organs were lyophilised and pulverised in a mixer mill of zirconium oxide. A $0.5 \mathrm{~g}$ portion of triturated samples was digested with nitric acid by heating in a microwave oven. The analytical determination of copper and zinc concentrations in the digest was performed by flame atomic absorption spectrometry. Cadmium, lead, chromium, nickel, arsenic and silver were analysed by electrothermal atomic absorption spectrometry with Zeeman background correction and STPF (Stabilised Temperature Platform Furnace) conditions. Mercury was determined by flow injection system-cold vapour atomic absorption spectrometry. More detailed methodology was described elsewhere (Saavedra et al., 2004).

\footnotetext{
Validation of the techniques used was performed by intralaboratory quality control using two certified reference materials (Table 1), CRM 278R: trace metals (except Ni and Ag) in mussel tissue from BCR (Community Bureau Reference) and NIST 1566 b: trace metals (Ni and Ag) in oyster tissue from NIST (National Institute of Standards and Technology).
} 


\section{Data processing}

The main factors responsible for the variation in metal concentrations as regards the different organs examined were studied by means of Principal Component Analysis. All the statistical analyses were carried out using the Minitab 15 statistical package.

\section{Results and Discussion}

Target organs. Metal concentrations in different organs of the scallops

There is a high degree of organ specificity to the different metals studied, with the exception of arsenic (Table 2). The nine metals may be classified into two groups on the basis of their anatomical distribution, using Principal Component Analysis (Fig. 3). The first group includes metals that are closely related to the first principal component (PC1), and is characterised by preferential accumulation in the kidney. The second group includes the metals that are more closely related to PC2, where preferential accumulation takes place in the digestive gland. As neither of the two organs is included in the edible portion of the scallops, comprising the muscle and gonad, it would follow that the edible organs contained very low concentrations of metals, with the highest concentrations of metals being found in either the digestive gland or the kidneys, except for arsenic.

\section{Arsenic}

Scallops had similar concentrations in the gills and digestive gland, and showed the lowest dispersion among organs. Arsenic would therefore seem to exhibit a different organ affinity than other metals, as it is more evenly distributed throughout the body. Arsenic distribution in Pecten maximus has not been studied to date, but the concentrations found were similar to those in Patinopecten yessoensis (Shiomi et al. 1988), who also observed no marked differences in arsenic concentration among tissues. 


\section{Cadmium}

In Pecten maximus from Galicia the digestive gland contains by far the highest cadmium concentrations. Other work studying cadmium in organs of this species from different areas also pointed to the digestive gland as a target organ (Segar et al. 1971; Topping, 1973 and Bryan 1973) in scallops from the Irish Sea, Scottish waters and Plymouth area, respectively. Most studies with other pectinids suggest that this is a general characteristic of this group of molluscs (Adamussium colbecki and Pecten jacobaeus, Mauri et al., 1990; Placopecten magellanicus, Greig et al., 1978; Uthe and Chou, 1987; Chlamys rosealbus, Khristoforova et al., 1989), with the possible exception of Mizuhopecten yessoensis in which Chelomin et al. (1995) reported the kidney as being an important organ of cadmium accumulation. Other bivalves would also appear to concentrate cadmium preferentially in the digestive gland, but the difference in concentration as compared to other organs is much lower than in pectinids. Different levels of this metal in the digestive gland have been found in the studied areas. Cadmium concentrations in the digestive gland of Galician scallops are similar to those found in scallops from the Irish Sea (Pecten maximus, Segar et al., 1971) and Antarctica (Adamussium colbecki, Viarengo et al. 1993). The highest concentrations recorded to date have been found in scallops from English Channel (Bryan, 1973), three times above the levels reported here. The lowest values have been reported in Scottish (Topping, 1973) and Adriatic (Mauri et al. 1990) scallops. It is important to consider that the differences cited in cadmium concentration may be due not only to different environmental levels of this metal, but also to the interspecific variation in the capacity of the scallops examined to concentrate cadmium in the digestive gland. This interspecific variation has been suggested by Bryan (1973) to explain differences in cadmium concentrations between Pecten maximus and Chlamys opercularis collected from the same area; and Mauri et al. (1990), who attributed a greater capability of cadmium accumulation in the digestive gland to Adamussium colbecki rather 
than to Pecten jacobaeus to explain higher values in the Antarctic as compared to Mediterranean areas.

\section{Chromium and copper}

In addition to cadmium, the digestive gland is a site of selective chromium and copper deposition, which is in agreement with previous studies (Mauri et al., 1990; Vashchenko et al., 2000; Zaroogian and Johnson, 1983). Notwithstanding, these metals are less selectively deposited than cadmium. The kidney is the second most important organ for chromium accumulation and gonads have copper concentrations similar to those of the kidney.

Zinc

The resulting data would point to the kidney as the target organ for zinc. Zinc concentrations in the kidney have been shown to be higher that those found in other organs of Pecten maximus in other studies with the same species (Bryan, 1973). However, the gonad has also been reported as an important organ, -the principal organ, in fact- of zinc concentration (Topping, 1973). Notwithstanding, the metal concentrations reported by Topping (1973), as in most of the studies, referred to mixed viscera (including the digestive gland and kidney), and the organ having the highest concentration of metals was unknown. Although the great capability of the kidney to concentrate zinc is also a characteristic of other scallop species (Mauri et al., 1990) and bivalves (George and Pirie, 1980, Ahn et al., 1996), few differences between the gonad and kidney were reported by Karaseva (1993) in females of Mizuhopecten yessoensis and most zinc concentrations appeared in the gills of other scallop species (Khristoforova et al., 1989; Khristoforova, 1996).

Zinc renal concentrations in Pecten maximus found in this study were lower than those from the English channel and Scottish waters, but higher than those in other scallops, which would 
corroborate the observations made by Mauri et al. (1990) that the kidney is a strong zinc accumulator in the genus Pecten .

\section{Mercury}

Our results point to the kidney as a target organ for mercury accumulation. The digestive gland was also found to contain higher concentrations than the rest of the tissues. As far as we know, this is the first study dealing with the anatomical distribution of $\mathrm{Hg}$ in Pecten maximus, so there are no other data available to support our findings. In other Pecten species, P. alba, Walker et al. (1982) found the highest levels of mercury in the inedible viscera which contains the digestive gland, among other organs.

\section{Lead}

This metal was concentrated preferentially in the kidney followed by the digestive gland. The concentration found in this latter organ was more than half as much as that found in kidney. Bryan (1973), studying scallops from Plymouth, also found a preferential concentration in the kidney, but the concentrations he found in this organ were one hundred times higher that those in digestive gland, instead of less that double, as found in this study, despite the fact that the scallops had similar total lead concentrations. Other forms of $\mathrm{Pb}$ or a different physiological status might be involved in this difference.

\section{Silver}

In this study the kidney displayed the most important silver concentrations and the digestive gland, foot and gonads had concentrations in the same order of magnitude as the kidney. Several other studies have pointed to the digestive gland as the main silver accumulator organ for Pecten maximus (Bryan, 1973, Segar et al., 1971) and the foot has been shown as one of the highest silver accumulator organs in Chlamys varia by Martoja et al. (1989). Notwithstanding, it is important consider that total concentrations in our study are smaller that 
those in the other studies we have cited and therefore, the difference in environmental availability may affect the anatomical distribution of this metal in the organisms under study.

\section{Nickel}

Here the results showed that nickel is selectively accumulated in the kidney, supporting the findings of Bryan (1973) who, in the same species, reported higher kidney than digestive gland concentration factors. In other studies, where the kidney was not separated as an individual fraction for nickel analysis, the most important nickel concentrations were found in the digestive gland of Pecten maximus (Segar et al., 1971), the digestive gland and gills of Chlamys rosealbus (Khristoforova et al., 1989), the visceral mass and gonads of Placopecten magellanicus (Greig et al., 1978) and the gills of Mizuhopecten yessoensis (Khristoforova, 1996).

Organ contributions-relative importance of metals in different tissues.

As cited above, the highest concentrations of metals are found either in the kidneys or digestive gland. The importance of each organ in determining the metal concentration of the whole soft tissues of a bivalve depends not only on the concentration but also on the weight of each specific organ. Taking this into account, the adductor muscle (the largest organ) appears as the principal contributor for mercury (38\% of the total metal burden), nickel (38\%), arsenic (56\%) and zinc (36\%) (Table 3). The digestive gland contained by far the greatest amount of cadmium ( $84 \%$ of total cadmium). Similar percentages have been reported in most studies on different scallop species (Uthe and Chou, 1987; Francesconi et al., 1993). The digestive gland was also the main contributor for chromium, copper, silver and lead; but, in the case of silver and lead, gonad and muscle contributions, respectively, were similar to those of the digestive gland. 


\section{Conclusions}

Two groups of metals were found on the basis of their anatomical distribution: one group was preferentially accumulated in the digestive gland and the other, in the kidney. As is the only metal homogeneously distributed among the different organs.

The adductor muscle and digestive gland were the organs that contributed in the greatest proportion to the total metal burden and therefore to metal concentration. Notwithstanding, the adductor muscle was only of primary importance in the case of arsenic, having, therefore, little repercussion on human health, as this metal appears to be found in scallops in a mostly non-toxic form. 
From a practical point of view, the presence of the maximum concentrations of metals, especially cadmium, in non-edible organs such as the kidney and digestive gland, together with the fact that the two most valuable organs of the scallop Pecten maximus for human consumption -the adductor muscle and gonad- were found to concentrate the metals at substantially lower levels than other organs, with the sole exception of arsenic, which was accumulated in only slightly lower concentration, opens the possibility of using selective evisceration of scallops to improve their quality for human consumption.

\section{References}

Ahn, I.-Y., Lee, S. H., Kim, K. T., Shim, J. H., Kim, D-Y. 1996. Baseline heavy metal concentrations in the antarctic clam, Laternula elliptica in Maxwell Bay, King George Island, Antarctica. Mar. Pollut. Bull., 32, 592-598.

Bryan, G.W. 1973. The occurrence and seasonal variation of trace metals in the scallops Pecten maximus and Chlamys opercularis. J. mar. biol. Ass. U.K. 53, 145-166.

Chelomin, V. P., Bobkova, E. A., Lukyanova, O. N., Chekmasova, N. M. 1995. Cadmium-induced alterations in essential trace element homoeostasis in the tissues of scallop Mizuhopecten yessoensis. Comp. Biochem. Physiol. 110C, 3, 329-335

Fernández, M.L., Shumway, S., Blanco, J., 2003. Management of shellfish resources. In: Hallegraeff, G.M., Anderson, D.M., Cembella, A. (eds.), Manual on Harmful Marine Microalgae. UNESCO Publishing, Paris. pp: 657-692.

Francesconi, K., A., Moore, E. J., Joll L. M., 1993. Cadmium in the saucer scallop, Amusium balloti, from western Australian waters: concentrations in adductor muscle and redistribution following frozen storage. Aust. J. Mar. Freshwater Res., 44, 787-97. 
George, S.G., Pirie, B. J.S., 1980. Metabolism of zinc in the mussel, Mytilus Edulis (L.): a combined ultrastructural and biochemical study. J. mar. biol. Ass. U.K., 60, 575-590.

Greig, R. A., Wenzloff, D. R., Mackenzie, Jr., Merrill, A. S., and Zdanowicz, V. S., 1978. Trace metals in sea scallops, Placopecten magellanicus, from Eastern United States. Bull. Envirom. Contam. Toxicol. 19: 326- 334.

Karaseva EM. 1993. Accumulation of heavy metals in gonads and somatic organs of bivalve mollusks. Biologiya Morya 2: 66-76.

Khristoforova, N. K., 1996. Metal concentration in tissues of the scallop Mizuhopecten yessoensis of different age. Russian Journal of Marine Biology, 22, 171-175.

Khristoforova, N. K., Kabun, V. Ya, Makhnyr, L. G., 1989. Heavy metals in soft tissues of the scallop chlamys rosealbus. Biol. Morya mar. Biol. 4, 64-70.

Lai, V. W.-M., Cullen, W. R., Ray, S., 1999. Arsenic speciation in scallops. Mar. Chem. $66,81-89$

Martoja, M., Truchet, M., Berthet, B. 1989. Effects de la contamination expérimentale par l'argent chez Chlamys varia 1. (bivalve, pectinidé). Données quantitatives, histologiques et microanalytiques. Ann. Inst. océanogr., 65, 1-13.

Mauri, M., Orlando, E., Nigro, M. and Regoli, F., 1990. Heavy metals in the Antartic scallop Adamussium colbecki. Mar. Ecol. Prog. Ser. 67, 27-33.

Saavedra, Y.; González, A.; Fernández, P.; Blanco, J. 2004. A simple optimized microwave digestion method for multielement monitoring in mussel samples Spectrochim. Acta Part.B. 59, 533-541.

Segar, D.A., Collins, J.D. and Riley, J.P. 1971. The distribution of the major and some minor elements in marine animals. Part II. Molluscs. J. mar. biol. Ass. U.K. 51, 131136. 
Shiomi, K., Sakamoto, Y., Yamanaka, H., Kikuchi, T. 1988. Arsenic concentrations in various tissues of bivalves and arsenic species in gills. Nippon Suisan Gakkaishi 54, 3, 539.

Stewart, P. L., Arnold, S. H., 1994. Environmental Requirements of the sea scallop (Placopecten Magellanicus) in Eastern Canada and its response to human impacts. Can. Tech. Rep. Fish. Aquat. Sci. 2005: ix + 36p.

Topping, G., 1973. Heavy metals in shellfish from Scottish waters. Aquaculture 1, 379384.

Uthe, J. F., and Chou, C. L., 1987. Cadmium in sea scallop (Placopecten magellanicus) tissues from clean and contaminated areas. Can. J. Fish. Aquat. Sci. 44, 91-98.

Vashchenko, M. A., Luchsheva, L. N., Bel'cheva, N. N., Syasina, I. G., and Silina, A. V., 2000. Assessment of the state of the japanese scallop Mizuhopecten yessoensis in Alekseeva Bight (Peter the Great Bay, Sea of Japan) based on morphological and biochemical parameters. Russian Journal of Marine Biology, 26, 342-349.

Viarengo, A., Canesi, L., Mazzucotelli, A. and Ponzano, E. 1993. Cu, Zn and Cd content in different tissues of the Antartic scallop Adamussium colbecki: role of metallothionein in heavy metal homeostasis and detoxication. Mar. Ecol. Prog. Ser. 95, 163-168.

Walker, T. I., Glover, J. W., Powell, D. G. M., 1982. Effects of length, locality and tissue type on mercury and cadmium content of the commercial scallop, Pecten alba Tate, from Port Phillip Bay, Victoria. Aust. J. Mar. Freshwater Res. 33, 547-52.

Zaroogian, G. E., Johnson, M. 1983. Copper accumulation in the Bay Scallop, Argopecten irradians. Arch. Environ. Contam. Toxicol. 12, 127-133. 
Table 1. Metal concentrations $\left(\mathrm{mg} \mathrm{Kg}^{-1}\right.$ ) in certified reference materials CRM $278 \mathrm{R}$ (As, Cd, $\mathrm{Cr}, \mathrm{Cu}, \mathrm{Hg}, \mathrm{Pb}$ and $\mathrm{Zn}$ ) and NIST $1566 \mathrm{~b}$ (Ni and $\mathrm{Ag}$ ).

\begin{tabular}{|c|c|c|c|c|}
\hline Element & Certified value & $\underline{\text { Uncertainty }}$ & This study & $\underline{\text { Recovery value }}$ \\
\hline $\mathrm{As}$ & 6.07 & $\underline{0.13}$ & $6.03+0.17$ & $\underline{99.3}$ \\
\hline $\mathrm{Cd}$ & 0.348 & $\underline{0.07}$ & $0.358+0.013$ & $\underline{102.9}$ \\
\hline $\mathrm{Cr}$ & 0.78 & $\underline{0.06}$ & $0.80+0.06$ & $\underline{102.6}$ \\
\hline $\mathrm{Cu}$ & 9.45 & $\underline{0.13}$ & $9.85+0.38$ & $\underline{104.2}$ \\
\hline $\mathrm{Hg}$ & 0.196 & $\underline{0.009}$ & $0.194+0.009$ & $\underline{99.0}$ \\
\hline $\mathrm{Pb}$ & 2.00 & $\underline{0.04}$ & $2.08+0.09$ & $\underline{104.0}$ \\
\hline $\mathrm{Zn}$ & 83.1 & $\underline{1.7}$ & $82.85+2.1$ & $\underline{99.7}$ \\
\hline $\mathrm{Ni}$ & 1.04 & $\underline{0.09}$ & $1.12+0.06$ & $\underline{107.7}$ \\
\hline $\mathrm{Ag}$ & 0.666 & $\underline{0.009}$ & $0.618+0.036$ & $\underline{92.8}$ \\
\hline
\end{tabular}


1

2 3 4

\author{
Table 2. Metal concentrations in the organs of Pecten maximus. Results were expressed as \\ mean and standard deviation of three batches.
}

$\begin{array}{cccccccccc}\text { Organ } & \mathbf{7 r} & \mathbf{C d} & \mathbf{M} \mathbf{P b} & \mathbf{C r} & \mathbf{N i} & \mathbf{A s} & \mathbf{A g} & \mathbf{C u} & \mathbf{Z n} \\ \text { Mantle } & 0.082 \pm 0.010 & 3.6 \pm 0.3 & 0.91 \pm 0.28 & 1.4 \pm 0.2 & 1.0 \pm 0.2 & 9.9 \pm 0.5 & 0.31 \pm 0.02 & 4.5 \pm 0.2 & 95 \pm 11 \\ \text { Gills } & 0.15 \pm 0.01 & 6.1 \pm 1.0 & 1.7 \pm 0.6 & 1.8 \pm 0.4 & 2.1 \pm 0.2 & 16 \pm 0.3 & 0.37 \pm 0.03 & 7.6 \pm 0.51 & 213 \pm 37 \\ \text { Gonad } & 0.070 \pm 0.003 & 2.6 \pm 0.2 & 1.1 \pm 0.1 & 0.82 \pm 0.31 & 1.1 \pm 0.1 & 8.5 \pm 0.9 & 0.57 \pm 0.06 & 15 \pm 1 & 223 \pm 16 \\ \begin{array}{c}\text { Digestive } \\ \text { gland }\end{array} & 0.24 \pm 0.01 & 120 \pm 8 & 4.8 \pm 0.4 & 5.2 \pm 0.6 & 3.3 \pm 0.3 & 15 \pm 0.9 & 0.67 \pm 0.04 & 28 \pm 2 & 210 \pm 24 \\ \text { Muscle } & 0.054 \pm 0.001 & 1.3 \pm 0.2 & 0.45 \pm 0.08 & 0.20 \pm 0.13 & 0.70 \pm 0.14 & 10 \pm 0.1 & 0.055 \pm 0.002 & 1.8 \pm 0.4 & 94 \pm 5 \\ \text { Kidney } & 0.70 \pm 0.05 & 1.8 \pm 0.1 & 7.5 \pm 2.2 & 2.7 \pm 0.8 & 14 \pm 2 & 11 \pm 1 & 1.5 \pm 0.10 & 18 \pm 1 & 7737 \pm 1459 \\ \text { Foot } & 0.064 \pm 0.003 & 5.6 \pm 1.3 & 0.95 \pm 0.10 & 1.2 \pm 0.1 & 1.6 \pm 0.4 & 8.3 \pm 0.4 & 1.1 \pm 0.1 & 6.5+1.0 & 75 \pm 8\end{array}$


Table 3. Contribution of each organ of scallop to total weight and metal content. Results were expressed as mean and standard deviation.

\begin{tabular}{|c|c|c|c|c|c|c|c|c|c|c|c|}
\hline Organ & $\begin{array}{l}\% \\
\text { W }\end{array}$ & $\% \mathrm{Hg}$ & $\% \mathrm{Cd}$ & $\% \mathrm{~Pb}$ & $\% \mathrm{Cr}$ & $\% \mathrm{Ni}$ & $\% \mathrm{As}$ & $\% \mathrm{Ag}$ & $\% \mathrm{Cu}$ & $\% \mathrm{Zn}$ & \\
\hline Muscle & 58 & $37,6 \pm 0,8$ & $6,1 \pm 0,2$ & $24,5 \pm 1,8$ & $11,0 \pm 5,1$ & $38,2 \pm 5,2$ & $55,6 \pm 1,1$ & $13,8 \pm 0,2$ & $16,2 \pm 3,6$ & $35,8 \pm 2,4$ & \\
\hline Mantle & 15 & $15,2 \pm 1,2$ & $4,6 \pm 0,1$ & $12,9 \pm 2,4$ & $21,7 \pm 2,2$ & $15,0 \pm 1,5$ & $14,3 \pm 0,8$ & $20,3 \pm 0,5$ & $11,0 \pm 0,9$ & $9,6 \pm 0,8$ & \\
\hline Gonad & 11 & $8,6 \pm 1,0$ & $2,3 \pm 0,3$ & $11,1 \pm 1,7$ & $9,1 \pm 4,1$ & $11,0 \pm 1,3$ & $8,6 \pm 0,8$ & $26,1 \pm 0,6$ & $26,1 \pm 3,6$ & $15,6 \pm 1,1$ & \\
\hline Gills & 5.8 & $10,4 \pm 0,6$ & $2,9 \pm 0,4$ & $9,1 \pm 2,5$ & $10,7 \pm 0,4$ & $11,8 \pm 3,2$ & $8,6 \pm 0,2$ & $9,2 \pm 0,1$ & $6,9 \pm 0,2$ & $8,1 \pm 1,7$ & \\
\hline Foot & 0.7 & $0,5 \pm 0,05$ & $0,3 \pm 0,1$ & $0,6 \pm 0,1$ & $0,8 \pm 0,2$ & $1,0 \pm 0,2$ & $0,5 \pm 0,01$ & $3,3 \pm 0,5$ & $0,7 \pm 0,2$ & $0,3 \pm 0,0$ & \\
\hline
\end{tabular}




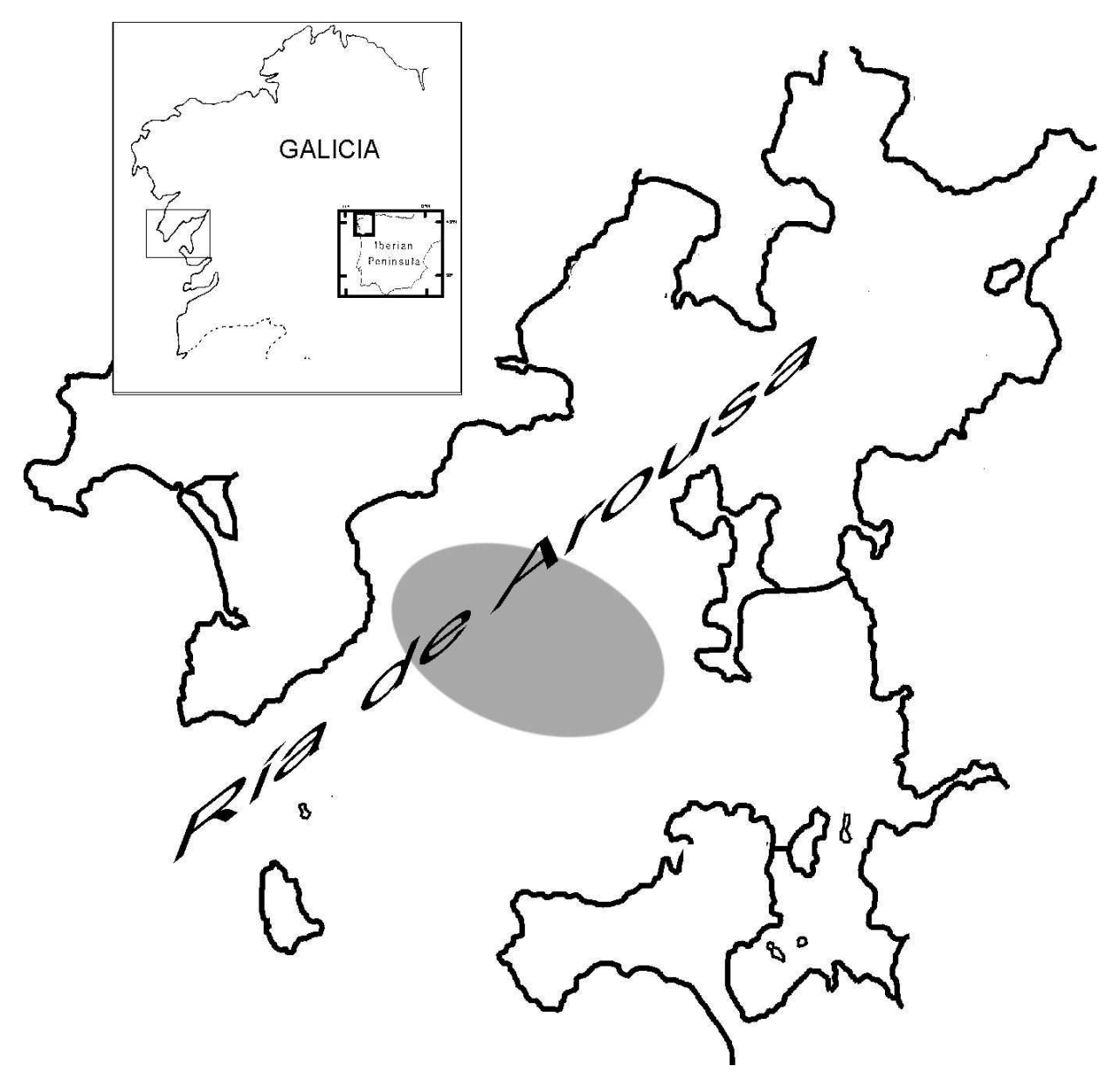

Sampling location (grey area) of scallops in the Ría de Arousa (NW Spain) $122 \times 112 \mathrm{~mm}(300 \times 300$ DPI $)$ 


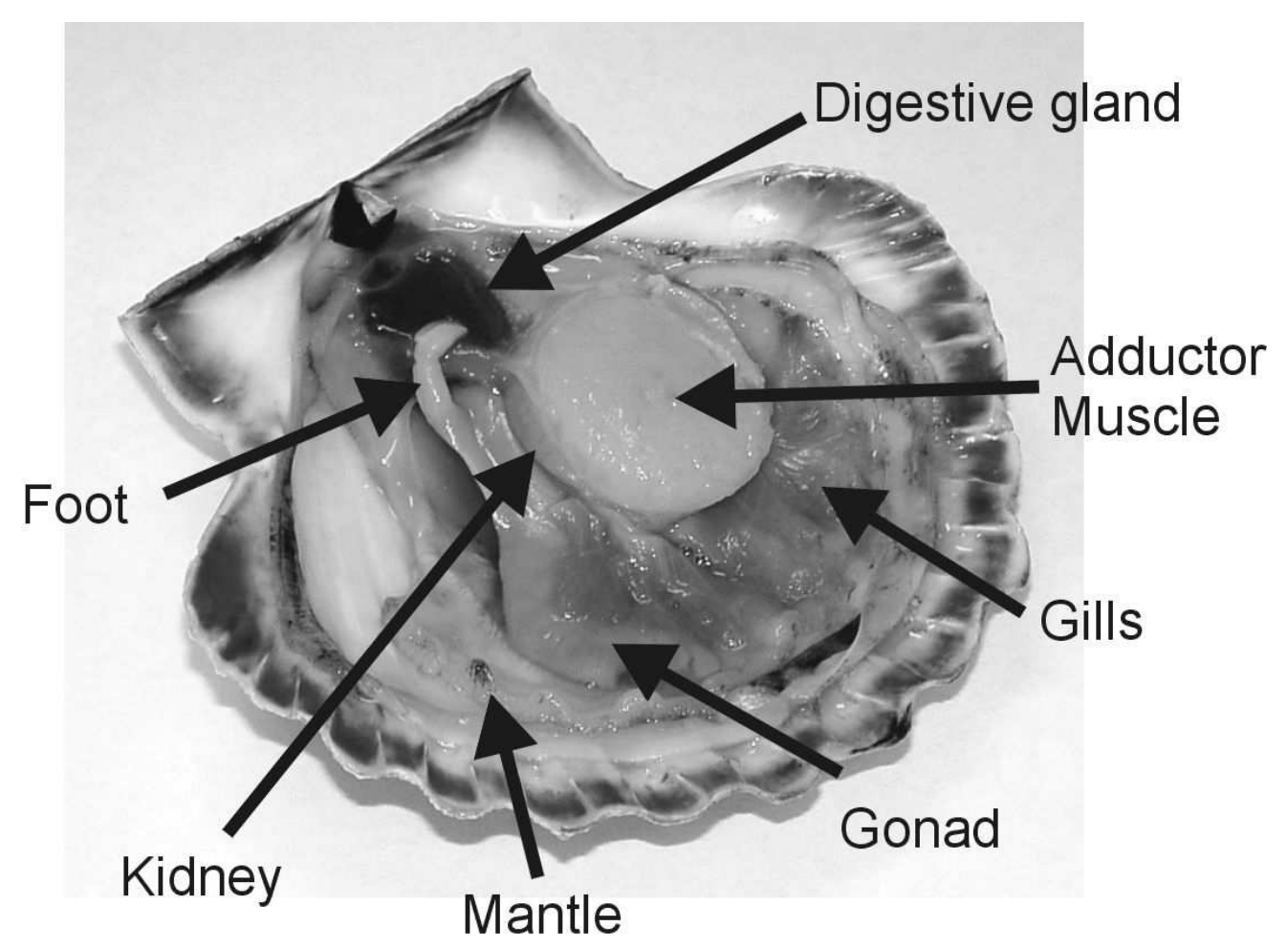

Fractions of the scallops dissected for metal concentrations analysis $70 \times 51 \mathrm{~mm}(400 \times 400 \mathrm{DPI})$ 
Loading plot of metal concentrations and the organs of more specific accumulation on the first two principal components. $370 \times 251 \mathrm{~mm}(96 \times 96 \mathrm{DPI})$ 